\title{
Artisan retention in an organisation in South Africa
}

\section{Authors:}

Lariska van Rooyen ${ }^{1}$

Danie H. du Toit ${ }^{1}$

Elrie Botha ${ }^{1}$

Sebastiaan Rothmann ${ }^{1}$

\section{Affiliations:}

${ }^{1}$ School of Behavioural

Sciences, North-West

University, South Africa

Correspondence to:

Sebastiaan Rothmann

email:

ian@ianrothmann.com

Postal address:

PO Box 2972, Vanderbijlpark

1900, South Africa

\section{Keywords:}

Artisan retention;

remuneration; development opportunities; qualitative research, South Africa

\section{Dates:}

Received: 04 May 2010

Accepted: 12 Aug. 2010

Published: 04 Nov. 2010

How to cite this article: Van Rooyen, L., Du Toit, D.H., Botha, E., \& Rothmann, S. (2010). Artisan retention in an organisation in South

Africa. SA Journal of Human Resource Management/SA Tydskrif vir Menslikehulpbronbestuur, 8(1), Art. \#300, 8 pages. DOI: 10.4102/sajhrm.v8i1.300

\section{This article is available} http://www.sajhrm.co.za

(C) 2010. The Authors. Licensee: OpenJournals Publishing. This work is licensed under the Creative Commons Attribution License.

\begin{abstract}
Orientation: South Africa is facing a critical shortage of artisans. Therefore it is important to investigate which factors contribute to the retention of artisans by organisations.
\end{abstract}

Research purpose: The objective of this study was to investigate the factors that are important for artisan retention at a South African organisation.

Motivation for the study: Organisations that employ artisans need to understand what the main reasons are for keeping or losing artisans from the perspective of the artisans themselves. This information can be used to plan and implement interventions to deal with artisan retention in organisations.

Research design, approach and method: A qualitative design was used and a purposive sample was taken $(n=14)$. A biographical questionnaire was administered and semi-structured interviews were conducted to gather data from artisans.

Main findings: Remuneration had the highest rank of all the factors for the retention of artisans, closely followed by development opportunities. Other factors that were perceived as important for artisan retention included equality, recognition, management and the working environment, and working relationships.

Practical implications: Organisations that employ artisans should especially attend to their remuneration and development opportunities.

Contribution: The results of this study add to the knowledge of why artisans remain with a specific organisation.

\section{INTRODUCTION}

Artisan retention in South Africa is important because the country is facing a critical shortage of artisans. It is crucial to have sufficient artisans in South Africa to enable infrastructure development, economic growth and wealth creation. According to the Centre for Development and Enterprise (CDE) (2007), an artisan is any employee who works as millwright, electrician, plumber, boilermaker, mechanic, fitter and turner, pattern maker or injection moulder. According to Jordaan and Barry (2009), 12500 artisans are needed per year, while recent statistics showed that approximately 3000 are passing the trade test per year. Artisan retention is particularly important, not only because the country is facing a critical shortage of artisans but also because the average age of an artisan is 54 years (CDE, 2007). This means that $70 \%$ of the artisans who are currently employed will exit the labour force within the next 5-6 years, which will only aggravate the current shortage of artisans and intensify the competition for talent. Organisations will have to implement strategies to keep artisans in their service.

Kleynhans (2007) states that many artisans are being recruited so intensively by Canada and Australia that local organisations have tried to counter this by offering more competitive salaries and retention bonuses. Reasons for international organisations' recruiting South African artisans are that past learnership programmes were recognised as world class and that many skilled artisans were eager to leave South Africa because of the high crime rate in the country (Jordaan \& Barry, 2009). According to Kleynhans (2007), some companies are now paying fitters and millwrights salaries of up to R30 000 per month just to retain them. These skills are rapidly becoming so scarce that organisations will go to extraordinary lengths to keep them.

According to Grobler, Wärnich, Carrell, Elbert and Hatfield (2006), employee turnover can be seen as the movement of employees out of the organisation. It is important to note that there are two types of employee turnover: the unpreventable and the preventable. The unpreventable refers to employee turnover that is beyond the control of both the organisation and the employee, for example, retirement or death. The preventable refers to employee turnover over which both the organisation and the employee have control, for example turnover related to resignations (Mengel, 2001).

Retention of artisans is necessary for various reasons. The decision of an employee to stay or leave is potentially costly, often between 1.5 and 2.5 times the annual salary of the incumbent (Wright, 2010). Losing employees has a significant economic impact on an organisation because of the concomitant loss of knowledge when they depart. Toracco (2000) states that although knowledge is recognised as one of an organisation's most important assets, most organisations lack the necessary support systems to retain knowledge. While organisations in South Africa might find it difficult to replace skilled artisans, Ramlall (2004) points out that employee retention is necessary to realise a full return on investment of an organisation in its employees.

Preventable artisan turnover has been a cause for serious concern in organisations for some time now, but few organisations have made an active effort to investigate why artisans are leaving. More 
importantly, organisations fail to recognise that artisans are leaving because not enough attention is given to retaining them by satisfying their needs. Although recruitment by international companies is a concern, the South African Institute of Race Relations (SAIRR) stated in 2007 that it was anticipated that local organisations would also recruit more aggressively from each other. The occurrence of aggressive local recruitment has been fuelled by higher rates of economic growth and the government's massive infrastructure spending. In addition, companies such as Eskom, Transnet and the Airports Company of South Africa are also implementing major infrastructural projects (SAIRR, 2007). If one looks at the scale of these projects, it becomes clear that it is essential for local organisations to explore alternative retention strategies to keep their artisans. Eskom, for instance, is planning capital expenditure expansions of R150bn up until 2011 and Transnet is expected to spend nearly R80bn on infrastructure between 2008 and 2012; thus one can imagine how many artisans will be needed for such large projects (SAIRR, 2007).

Even though some local organisations have been trying to retain their artisans by offering more competitive salaries or sign-on and retention bonuses, these strategies are often unsuccessful. According to De Lange (2007), some organisations began to offer artisans sign-on bonuses on condition that they stay with the organisation for at least two years. Some organisations have even implemented an allowance strategy, which means that they pay artisans a $33 \%$ allowance on top of their salaries just to retain them. If incentives such as these are not enough to retain artisans, the question arises, 'What do they really want?'

Before strategies can be implemented to retain artisans, it is necessary to establish what it is that artisans want from an employer. According to Levin, Mor Barack and Nissly (2001), organisations must know which factors motivate their employees to stay and which factors cause them to resign if they are to retain them.

Many managers refer to artisans as 'blue-collar' or 'semiskilled' workers, as if they are always dirty, semi-literate and unable to express themselves intelligently. In addition, organisations shun artisans when it comes to recognising their efforts through profit-sharing schemes. Kleynhans (2007) argues that should organisations want to make an active effort to retain their artisans, they will have to consider improving their human resource practices by reviewing the opportunities that are available to artisans. Opportunities regarding career paths, promotions and scope for training and development should be critically investigated. It seems that artisans want opportunities to develop as people, not only to be better workers (Kleynhans, 2007).

Artisans report that their salaries are too low, but it also seems that development opportunities for them are not taken seriously (Jordaan \& Barry, 2009). Therefore, it seems logical to look at the problem from a motivational perspective. To retain employees, employers must know what factors motivate their employees to stay and what factors cause them to leave (Levin et al., 2001). Therefore, organisations will have to make an active effort to find out exactly what it is that artisans want in order for them to be retained. According to Kaye and Jordan-Evans (2002), organisations simply have to ask employees what they want, but managers are often reluctant to ask employees this question because they fear that they might create expectations that the organisation might not be able to satisfy. Although this might be a real concern for managers, Kaye and Jordan-Evans (2002) also state that asking employees what they want is a very important part of communication between the organisation and the employee because it has positive side effects. The employee who is asked what he or she wants will feel cared for, valued and important and this will often lead to stronger loyalty and commitment to the organisation. Thus, merely asking this question is in itself a retention strategy.
Based on the above-mentioned discussion, the research problem could be summarised as follows: A shortage of artisans exists in South Africa. Therefore, organisations that employ artisans need to understand what the main reasons are for keeping or losing artisans, from the perspective of the artisans themselves. This information can be used to plan and implement research projects as well as human resource programmes to investigate and deal with the issue of artisan retention in organisations. The objective of this study was to investigate the factors that are important for artisan retention in an organisation in South Africa.

\section{RETENTION}

According to Mengel (2001), retention refers to an organisation's efforts to keep in employment those employees of whom the organisation has a positive evaluation and who would normally only leave the organisation through voluntary resignation.

Ramlell (2004) analysed motivation theories to offer an explanation of how employee motivation affects employee retention within an organisation. The following critical factors that affect the retention of employees were identified (Ramlell, 2004):

- Satisfaction of the needs of the employee: An individual has multiple needs based on individual, family and cultural values.

- Work environment: Employees want to work in a productive, respectful and friendly environment.

- Responsibilities: Given that an employee feels competent to perform, he or she might seek additional responsibilities and want to be rewarded in a fair and equitable manner.

- Supervision: Some individuals might feel a need to coach and develop others and to influence the organisation's goals and objectives.

- Fairness and equity: Employees want to be treated in a fair and equitable manner and do not want to be discriminated against.

- Effort: Employees want the task to be challenging and satisfying.

- Employee development: Employees want to work in an environment that provides a challenge, offers new learning opportunities and offers opportunities for advancement and development.

- Feedback: Employees want to receive timely and open feedback from their supervisors.

From the perspective of self-determination theory (Ryan \& Deci, 2002), two types of motivation can be distinguished: intrinsic and extrinsic motivation. Intrinsic motivation is displayed when an activity is undertaken out of interest, enjoyment or inherent satisfaction. Intrinsic motivation can be divided into three parts, namely intrinsic motivation to know, intrinsic motivation towards accomplishment and intrinsic motivation to experience stimulation. Three needs of individuals need to be satisfied to stimulate intrinsic motivation, the needs for autonomy, competence and relatedness (Gagné \& Deci, 2005). The proposition of self-determination theory is that extrinsic motivation can vary in the degree to which it is autonomous versus controlled. Activities that are not intrinsically motivating require extrinsic motivation. Extrinsic motivation relates to activities undertaken for other reasons than interest in the activity and can be classified as integration, identification, introjections and external regulation (Ryan \& Deci, 2002). Integrated regulation occurs when an activity is recognised as worthwhile because it is seen as a means to an end. Identification occurs when individuals identify that an activity is worthwhile for a specific reason. Introjected regulation is governed by rewards and restrictions implemented by individuals themselves. External regulation is governed by rewards and restrictions implemented by others. The latter type of motivation is the lowest type of motivation on the selfdetermination continuum. 
According to Gagné and Deci (2005), work climates that promote satisfaction of the three basic psychological needs will enhance employees' intrinsic motivation, promote internalisation of extrinsic motivation and lead to organisational commitment, which will contribute to retention of staff. In this regard, autonomy-supportive interpersonal environments play the most significant role. Three specific factors, namely a meaningful rationale for doing a task, acknowledgement that people might not find an activity interesting and an emphasis on choice rather than control facilitate internalisation of extrinsic motivation. Employees' intrinsic motivation and internalisation of extrinsic motivation contribute to two components of organisational commitment, namely identification with an organisation and internalisation of its values.

According to Harris and Brannick (1999), there are many factors that can influence an individual's motivation for staying with an organisation, but just as every employee has a unique background, these factors, too, are unique to each individual. An important factor to remember, according to Buhler (2003), is that employees need change over time. Therefore, Buhler adds that it does not mean that once an employee's position in the hierarchy is identified, it will continue to hold true. The ideal would be for managers to take responsibility for reassessing the needs of employees regularly in order to establish which factors are important for them at that moment in time.

Kaye and Jordan-Evans (2002) completed an international research project with 8000 participants in 35 different industries to establish the most common reasons why people stay with an organisation. The most important factors for employee retention (in order of importance) include exciting work and challenge, career growth, learning and development, fair pay, relationships and working with agreeable people, supportive management, pride in the organisation, its mission and its products, congenial work environment or culture, being recognised, meaningful work and autonomy. In a study that focused on artisans in South Africa, Jordaan and Barry (2009) found that insufficient remuneration, lack of training opportunities and unpleasant working conditions were the main reasons for the current shortage of artisans in South Africa. Organisational factors that affect artisan retention include working conditions, management style and approach, and fair treatment.

\section{RESEARCH DESIGN}

\section{Research approach}

This study was exploratory in nature and a qualitative design was used. According to Sarantakos (1998), research that is exploratory in nature is usually carried out when there is not sufficient information about the subject under investigation or when the formulation of hypotheses is difficult or impossible. Semi-structured interviews were used to collect the data. The researchers collected data from participants until data saturation was reached, in other words, until no more new information manifested. Data saturation was reached by interview number 11, but it was decided to complete all 14 interviews to honour the commitment to the participants.

\section{Research method \\ Participants}

The total population of artisans working in the same department of a chemical organisation $(N=32)$ was targeted in this research. Only participants who hold a formal qualification as an artisan as prescribed by Sector Education and Training Authority (SETA) standards participated in the study. A purposive sample of artisans was taken based on two additional criteria, namely that they were willing to participate in the study and that they were able to talk about their experiences. Although all the participants could have participated, it was decided to continue with the interviews until data saturation was reached. The final sample consisted of 14 artisans. Descriptive information of the sample is given in Table 1.
TABLE 1

Characteristics of the participants

\begin{tabular}{|c|c|c|c|}
\hline Item & Category & Frequency & Percentage \\
\hline \multirow[t]{4}{*}{ Age } & $20-29$ years & 1 & 7 \\
\hline & $30-39$ years & 6 & 43 \\
\hline & $40-49$ years & 4 & 29 \\
\hline & $50-59$ years & 3 & 21 \\
\hline \multirow[t]{2}{*}{ Gender } & Female & 0 & 0 \\
\hline & Male & 14 & 100 \\
\hline \multirow[t]{4}{*}{ Race } & Asian & 0 & 0 \\
\hline & Black & 3 & 21 \\
\hline & Coloured & 0 & 0 \\
\hline & White & 11 & 79 \\
\hline \multirow[t]{6}{*}{ Home language } & Afrikaans & 9 & 64 \\
\hline & English & 2 & 14 \\
\hline & Sepedi & 1 & 7 \\
\hline & Setswana & 1 & 7 \\
\hline & isiXhosa & 1 & 7 \\
\hline & Other & 0 & 0 \\
\hline \multirow[t]{3}{*}{ Marital status } & Single & 1 & 7 \\
\hline & $\begin{array}{l}\text { Married or living with a } \\
\text { partner }\end{array}$ & 11 & 79 \\
\hline & Divorced & 2 & 14 \\
\hline \multirow{5}{*}{$\begin{array}{l}\text { Number of } \\
\text { dependants }\end{array}$} & 0 & 2 & 14 \\
\hline & 1 & 4 & 29 \\
\hline & 2 & 7 & 50 \\
\hline & 3 & 1 & 7 \\
\hline & More than three & 0 & 0 \\
\hline \multirow[t]{5}{*}{ Education } & Grade 10 & 2 & 14 \\
\hline & Grade 11 & 0 & 0 \\
\hline & Grade 12 & 9 & 64 \\
\hline & Technical college diploma & 3 & 21 \\
\hline & $\begin{array}{l}\text { University of technology } \\
\text { diploma }\end{array}$ & 0 & 0 \\
\hline \multirow[t]{2}{*}{ Employment status } & Temporary & 0 & 0 \\
\hline & Permanent & 14 & 100 \\
\hline \multirow[t]{3}{*}{ Years of service } & One to 10 & 9 & 64 \\
\hline & Eleven to 20 & 4 & 29 \\
\hline & 21 years or more & 1 & 7 \\
\hline \multirow[t]{11}{*}{ Rate per hour } & R54 or below & 0 & 0 \\
\hline & $\mathrm{R} 55-\mathrm{R} 60$ & 3 & 21 \\
\hline & R61 - R65 & 0 & 0 \\
\hline & $\mathrm{R} 66-\mathrm{R} 70$ & 0 & 0 \\
\hline & $\mathrm{R} 71-\mathrm{R} 75$ & 0 & 0 \\
\hline & $\mathrm{R} 76-\mathrm{R} 80$ & 1 & 7 \\
\hline & $\mathrm{R} 81-\mathrm{R} 85$ & 3 & 21 \\
\hline & $\mathrm{R} 86-\mathrm{R} 90$ & 1 & 7 \\
\hline & R91 - R95 & 1 & 7 \\
\hline & R96 - R100 & 1 & 7 \\
\hline & R101 or more & 4 & 29 \\
\hline \multirow[t]{4}{*}{ Artisan trade } & Instrumental & 6 & 43 \\
\hline & Electrical & 3 & 21 \\
\hline & Fitting & 4 & 29 \\
\hline & Welding & 1 & 7 \\
\hline \multirow[t]{2}{*}{ Union member } & No & 10 & 71 \\
\hline & Yes & 4 & 29 \\
\hline
\end{tabular}

Table 1 shows that the sample consisted entirely of male participants $(100 \%)$ who were mainly Afrikaans-speaking $(64 \%)$. A majority total of $43 \%$ of the sample were between the ages of 30 and 39 years. Most of the participants reported that they were married $(79 \%)$. Half of the sample $(50 \%)$ reported that they had two dependants. The entire sample $(100 \%)$ was permanently employed and most (64\%) of the participants had been working for the organisation for a period of one to 10 years. Most of the participants held a Grade 12 certificate (64\%) and $29 \%$ reported that they received an hourly rate of R100 or more. Generally, participants (43\%) followed an instrumental trade. The majority of participants $(71 \%)$ did not belong to a labour union.

\section{Data gathering}

A self-constructed questionnaire was used to obtain the biographical characteristics of the participants, which included age, gender, language, race, marital status, number of dependants, years of service and level of educational qualification. The biographical questionnaire allowed the participants to remain anonymous. 
A qualitative data-gathering technique (an interview) was used in this study. The researcher studies the phenomenon without predetermined expectations or categories and tries to understand the data from the perspective of the participant (Moustakas, 1994). Possible interview questions for the purpose of the semi-structured interviews were constructed and identified beforehand by using the literature study, problem statement and research objectives as guide. Two questions were asked, namely, 'What are the main reasons why you think this company is losing artisans?' and 'What will make you stay at this company?'

The researcher's attitude was one of unconditional positive regard. Nondirective conversation techniques, for example minimal encouragement, attentive listening, clarification, paraphrasing, reflecting and summarising, were used to gather information. Enough time was allowed and a relaxed atmosphere was created to help the participants to feel at ease.

\section{Research procedure}

The researcher selected the sample to consist only of participants in possession of a formal qualification as an artisan as prescribed by SETA standards. Letters were sent to the participants in order to explain the nature of and reasons for the research. It is important to note that participation in the research was completely voluntary and that no direct or subtle coercion occurred in the recruitment process. Participants did not receive any benefits or compensation for taking part in the study and feedback on the results was given only to individuals who requested it. Participants were ensured that their responses were confidential. Each participant was afforded the opportunity to remain anonymous during the interview process as well as when completing the questionnaires. Research collection sessions were scheduled at a time that was convenient for the participants and occurred chiefly during the participants' lunch hour.

\section{Data analysis}

Content analysis was used to analyse, quantify and interpret research data systematically and objectively. The universe of the content to be analysed was defined and categorised. The units of analysis, words and themes were determined by reading through the written transcriptions of the data. Dominant themes and subthemes were determined. The themes were coded. Coding can be seen as the process of grouping evidence and labelling ideas so that they reflect increasingly broader perspectives (Creswell \& Clark, 2007)

The reliability of the qualitative data was checked by completing the procedure of inter-coder agreement. This method uses several individuals to code a transcript and then compare their findings to establish whether they have arrived at the same codes and themes or at different ones (Miles \& Huberman 1994). Furthermore, the researcher made use of peer validation to optimise the validity of the qualitative data (Creswell 1998). Themes were checked and verified by two industrial psychologists for confirmation and/or criticism. After both inter-coder agreement and peer validation were achieved, the qualitative data were transformed into quantitative data in order to compare the data and to analyse the data set as a whole. The concrete language used by the participants was translated to scientific language and concepts. The exact words of the participants were used as proof and themes were confirmed by literature references.

\section{RESULTS}

The answers to the questions applicable to the retention of artisans were combined. If a response occurred more than once for a single participant, it was counted only once. Table 2 below shows an overview of themes from the participants' descriptions regarding the factors that are important for artisan retention.

The following deductions can be made on the basis of the results in Table 2 regarding factors that are important for artisan retention.

- Theme 1: Remuneration (Rank $=1)$

This theme was mentioned by all 14 participants and can therefore be seen as the most important factor for artisan retention. Remuneration refers to the reward that an employee receives for working for the organisation. Remuneration includes pay, salary or wages, including allowances, benefits (such as company car, medical plan or pension plan), bonuses and other cash incentives. The importance of remuneration as a retention factor is confirmed by the following remarks from the participants, 'The money here isn't very good', 'There are different issues at every company, but with this one it is money, '... benchmark our salaries ...', 'The money overseas is much better than here', 'They should critically look at our salary scale ...' and '... pay us what we're worth'. Kaye and JordanEvans (2002) state that if employees see remuneration as being noncompetitive, unfair or insufficient to sustain life, they will be largely dissatisfied.

- Theme 2: Development opportunities (Rank = 2)

This theme was mentioned by 13 participants, who regarded development opportunities as an important factor for artisan retention. Employee development can be seen as a joint, ongoing effort on the part of an employee and the organisation for which the individual works to upgrade the employee's knowledge, skills and abilities. Successful employee development requires a balance between an

TABLE 2

Important factors for artisan retention

\begin{tabular}{|c|c|c|c|c|c|c|c|c|c|c|c|c|c|c|c|c|}
\hline \multirow[b]{2}{*}{ Theme } & & \multicolumn{15}{|c|}{ Frequency } \\
\hline & & Rank & 1 & 2 & 3 & 4 & 5 & 6 & 7 & 8 & 9 & 10 & 11 & 12 & 13 & 14 \\
\hline 1 & Remuneration & 1 & & & & & & & & & & & & & & \\
\hline 2 & Development opportunity & 2 & & & & & & & & & & & & & & \\
\hline 3 & Equality & 3 & & & & & & & & & & & & & & \\
\hline 4 & Recognition & 4 & & & & & & & & & & & & & & \\
\hline 5 & Management & 5 & & & & & & & & & & & & & & \\
\hline 6 & Working environment & 5 & & & & & & & & & & & & & & \\
\hline 7 & Working relationships & 6 & & & & & & & & & & & & & & \\
\hline 8 & Merit system & 7 & & & & & & & & & & & & & & \\
\hline 9 & Job satisfaction & 7 & & & & & & & & & & & & & & \\
\hline 10 & Change management & 7 & & & & & & & & & & & & & & \\
\hline 11 & Belongingness & 7 & & & & & & & & & & & & & & \\
\hline 12 & Employee wellness & 7 & & & & & & & & & & & & & & \\
\hline 13 & Job Security & 7 & & & & & & & & & & & & & & \\
\hline
\end{tabular}


individual's career needs and goals and the organisation's need to get the work done.

According to the participants of this study, development opportunities are almost as important for artisan retention as remuneration. The importance of development opportunity as a retention factor can be confirmed by the following remarks of the participants: 'If they want to keep us, they need to look at development practices more often', '... as long as they keep on providing me with opportunities for development and growth I will stay', '... training and development should be done on a more personal level than on corporate level', 'We are told that we can study anything related to our field, but they do not take the time to tell us what careers are available in our field' and 'I will only stay with a company if I believe they want to develop my skills further'.

- Theme 3: Equality (Rank $=3$ )

This theme was mentioned by five participants, who reported that they viewed equality as an important factor for artisan retention. The participants expressed their views on equality as follows, 'We do not get the same opportunities ...', 'The Employment equity guys are fasttracked ...' 'I want all the privileges and opportunities that everyone else is getting ...' and 'Everyone should be treated equal'. In this light, it seems that equality is an important factor for artisans. This might be due to the fact that organisations are implementing employment equity more rigorously than before in order to ensure that black employees and minorities are well represented in the artisan field and, as a result, the other employees are viewing it as inequality. This statement can be supported by the following remarks by the participants, 'Employment equity should not be implemented so rigidly', 'Employment equity is a big problem' and 'Employment equity is hampering my success at the company'.

- Theme 4: Recognition (Rank =4)

This theme was mentioned by four participants, who reported that they viewed recognition as an important factor for artisan retention. The remarks of the participants regarding recognition are as follows, 'Give me more recognition ...', 'They should really make us feel more important, because at this stage I am only feeling like a number' and 'If you work hard they should notice it'.

- Theme 5: Management (Rank = 5)

This theme was mentioned by three participants, who reported that they viewed management as an important factor in artisan retention. The participants expressed their views about management as follows, 'Management is a problem ...' and 'Certain managers aren't correct for the group, and that causes conflict'.

- Theme 6: Working environment (Rank = 5)

This theme was mentioned by three participants, who reported that they viewed the working environment as an important factor for artisan retention. In the context of this research, working environment can be viewed as the place where the artisans work. The participants expressed their views about the working environment as follows, 'The guys of today want to work in a clean environment' and 'We have a nice environment'.

- Theme 7: Working relationships (Rank $=6$ ) This theme was mentioned by two participants, who reported that they viewed working relationships as an important factor for artisan retention. Working relationships in the context of this study can be seen as the relationship between employees and management and the relationship between employees and their co-workers. The following comment from one of the participants supports the view that working relationships are an important factor for artisan retention, '... foster better working relationships between management, line management and the artisans'.

- Theme 8: Merit system (Rank = 7)

This theme was mentioned by one participant, who reported that he viewed the company's merit system as an important factor for artisan retention. The merit system in the context of this study can be seen as the organisation's official performance management system. The participant shared his view on the merit system as follows, 'The merit system is useless; it does not matter what grade they give us, we still get the same raise'. Although only one participant mentioned the merit system as a factor for artisan retention, when asked what they would change about the organisation, five participants mentioned that they would change the merit system. The comments regarding the merit system included the following, 'I do not see the use of having a merit system if the unions negotiate your raise in any case', 'I am a group leader and when we do merits I get a hybrid point; they need to change the merit system because it is demoralising' and 'They should not compare the different trades with each other when doing the merits'.

- Theme 9: Job satisfaction (Rank = 7)

This theme was mentioned by one participant, who reported that he viewed job satisfaction as an important factor for artisan retention. This participant shared his view on job satisfaction as follows, '... the guys do not have job satisfaction'.

- Theme 10: Change management $($ Rank $=7)$

This theme was mentioned by one participant, who reported that he viewed change management as an important factor for artisan retention. This participant shared his view on change management by remarking, '... if they want to implement change, they need to manage it well'.

- Theme 11: Belongingness (Rank = 7)

This theme was mentioned by one participant, who reported that he viewed belongingness as an important factor for artisan retention. In the context of this research, belongingness can be viewed as the participant's need to be and feel part of a cohesive team and organisation. The participant voiced his view regarding belongingness as follows, 'I want to feel at home and I want to feel part of a team, because at this stage I only feel like a number'.

- Theme 12: Employee wellness (Rank = 7)

This theme was mentioned by one participant, who reported that he viewed employee wellness as an important factor for artisan retention. The participant shared his view on employee wellness as follows, 'Employee wellness is a big thing and they need to give more attention to it'. Although only one participant mentioned employee wellness as a factor for artisan retention, when asked if they would be interested in wellness in the workplace, 12 of the participants answered 'yes' and only two answered 'no'. The statements regarding employee wellness were as follows, 'Regular health check-ups would be really nice', 'We could do with something like stress management or something like that' and 'I am sure the guys would like it if we could play something like table tennis during breaks'.

- Theme 13: Job security (Rank = 7)

This theme was mentioned by one participant who reported that he viewed job security as an important factor for artisan retention. He shared his view on job security as follows, 'I want security regarding my job.' Although only one participant stated that he perceived job security as an important factor for artisan retention, when asked to what extent they had job security, all of the participants stated that they believed their jobs to be secure. 


\section{DISCUSSION}

The objective of this study was to establish the factors that are important for artisan retention in an organisation. The results indicate that remuneration is perceived as the most important factor for artisan retention, followed by development opportunities. Other factors that were also perceived as important for artisan retention by the participants included equality, recognition, management and the working environment and working relationships. Factors that were mentioned by only one participant each include change management, job security, belongingness, the merit system, job satisfaction and employee wellness.

Various factors that are important for employee retention, as identified by Ramlall (2004), were also reported in this study, namely needs of artisans (e.g. which might be satisfied through fair remuneration), the work environment, recognition and feedback by supervisors, equitable treatment and development However, it seems that remuneration and development opportunities were most frequently noted as factors that are important to retain artisans.

Remuneration can be regarded as the most important factor for artisan retention. This finding is in line with the findings of Parker and Wright (2000). Jordaan and Barry (2009) conducted a similar study on employment factors that could contribute to artisan retention and they found that $40 \%$ of 79 participants reported that remuneration was the dominant employment factor for artisan retention. In addition, fair pay was listed third on the list of retention factors as researched by Kaye and Jordan-Evans (2002), which supports the findings of this study that remuneration is a major role player in artisan retention.

According to Jordaan and Barry (2009), salary levels of artisans should be critically evaluated because they are perceived as low. They point out that salary level is perceived to be the main employment factor that is important for the retention of artisans. Companies are paying vast amounts in remuneration in order to retain their artisans (Kleynhans, 2007). This means that artisans are in a favourable position and might be able to use this position to negotiate with organisations in order to be retained and to gain the most from the current situation. Willis-Shattuck et al. (2008) analysed various studies regarding motives of health workers and found that remuneration was regarded as important by employees in almost all studies. In addition, they pointed out that remuneration should be integrated with other incentives, particularly if the aim is to retain employees. Employees who were paid low salaries felt that their skills were not valued.

Due to the artisan shortage in the country, organisations have no choice but to negotiate with their employees about their remuneration. The only other option is to allow them to leave, but for organisations to recruit new employees in the present circumstances is out of the question. However, remuneration should not be relied upon as the sole strategy for retention. Kaye and Jordan-Evans (2002) support this notion by stating that an above-market-related wage alone will not keep employees; organisation have to create challenges and growth opportunities for employees and care about their well-being in order to retain them. According to Chew (2005), traditional approaches that rely heavily on competitive remuneration often have limited success in staff retention in the long run.

Thirteen participants reported that they viewed development opportunities as an important factor for artisan retention. The opportunity to develop was second on the list of important retention factors, according to Kaye and Jordan-Evans (2002) In addition, Jordaan and Barry (2009) found that better development opportunities accounted for $14 \%$ of the answers of the participants in their study when asked what they perceived to be the most important employment factors for artisan retention. However, it seems that artisans are not preparing themselves for higher positions by formal qualifications and training. Education and training opportunities have strong motivating effects (Willis-Shattuck et al., 2008). Training enables artisans to take on more demanding duties and to achieve personal goals of advancement and ultimately allows them to cope better with the requirements of their job. Ryan and Deci (2002) regard competence as an important need of people. Development opportunities are therefore necessary to satisfy artisans' needs for competence.

The Harvard Business School (2006) states that best-practice companies have already recognised the value of development as a retention factor and that they are focused on encouraging employees not to chase remuneration but instead to chase responsibilities and learning opportunities. Simpson (2002) supports this assertion, stating that talented individuals seek opportunities for development and that they look for organisations that will be able to provide them with the necessary opportunities to allow them to develop competencies that can be useful to them in future. In summary, the Harvard Business School (2006) holds that development is one of the most effective ways of retaining and rewarding talented staff.

Chew (2005) found that organisations regard it as too costly to train employees beyond the required basic skills. Organisations are often reluctant to provide developmental training because it is seen as a threat to staff retention. This reluctance may also be due to the need to offer better pay packages given that training enhances job mobility. Bassi and Van Buren (1999) state that when the training and development needs of employees and employers are met, the chances are greater that employees will stay in their organisations. Therefore, one can assume that the opposite also holds true and that if the needs of employees regarding development opportunities are not met, they will leave the organisation. Bearing in mind that the factor of development opportunity was ranked second and was therefore perceived as being of high importance, one can conclude that organisations, in addition to the current remuneration packages that they offer, will have to place more emphasis on making more development opportunities available to artisans if they want to retain their artisan talent.

The third factor that the artisans reported as being important for retention was equality. Five participants mentioned this factor. According to Newell (2002), equality can be viewed as a conscious effort by the organisation to create equal opportunities for all and eliminate unfair discrimination. Totta and Burke (1995) add that real equality fosters an environment where all employees have equal access to career development and advancement opportunities and all employees are actively encouraged to reach their full career potential. Equality does not feature as a retention factor on the list of factors of Kaye and Jordan-Evans (2002), but it does feature on the list of organisational retention factors as researched by Jordaan and Barry (2009). In their study, Jordaan and Barry found that fair treatment was mentioned by $41 \%$ of 79 participants as an important factor for retention. Newell (2002) holds that if employers want to bring about real change regarding equal opportunities, passive support is not an option; they need to be truly committed to promoting holistic equality before they will be successful. Perceptions of equality might affect artisans perceptions of fairness of processes, procedures and outcomes of human resource management decisions (see Jordaan \& Barry, 2009).

Recognition was mentioned by four participants, which resulted in the factor having a ranking of fourth place. Recognition features eighth on the list of important retention factors of Kaye and Jordan-Evans (2002) and fourth on the employment retention factors list of Jordaan and Barry (2009). This might be an indication that recognition is more of a general retention factor than a retention factor specifically for artisans. Dibble (1999) states that if organisations want to retain employees, they need to build connections with them by recognising their efforts and telling them that they are valuable to the organisation. This will create a reason for them to stay with the organisation. 
The artisans reported management and the working environment as the fifth most important factor for retention. This could be due to the fact that employees want to foster a good working relationship with management, one that does not involve frequent conflict. Abraham (2007) states that a poor relationship with a manager is one of the primary reasons people become dissatisfied. The Harvard Business School (2006) supports this, stating that people do not leave companies; they usually leave their managers. Management features more prominently as a retention factor in the study of Jordaan and Barry (2009) in that it accounts for $44 \%$ of the organisational factors that can retain artisans. Management also features as number five on Kaye and Jordan-Evans' (2002) list of retention factors.

McCarter and Schreyer (2000) state that employees want to work in clean, comfortable surroundings; whether employees work in an office or an auto repair shop, they are much happier and more satisfied if their surroundings are neat, orderly and clean. With reference to the factor of working relationships, two participants mentioned this factor, which gave it a ranking of sixth place. The factor of working relationships features fourth on the list of Kaye and Jordan-Evans (2002) but does not feature on the list of Jordaan and Barry (2009), indicating that this might be more of a general need than one that is specific to the artisan environment. Jordaan and Barry found that a better working environment (organisational retention factors) accounted for $53 \%$ of their sample's answers. In addition, according to the study by Kaye and Jordan-Evans (2002), the working environment featured at number seven on their list of retention factors, indicating that although it did not feature prominently on this study's list, it is a factor worthy of investigation.

The merit system, job satisfaction, change management, belongingness, employee wellness and job security were mentioned by one participant as an important factor for the retention of artisans. The merit system could be referring to an esteem need because, in essence, the merit system is nothing more than a method that is used to determine how well individuals are performing at their vocation in order to give recognition to excellence and implement corrective measures for underperformance.

Weak employee organisational linkages are often displayed as the phenomenon of turnover. Indeed, artisans are likely to resign to obtain better monetary rewards and development opportunities. Although nonfinancial factors are also important for artisan retention, satisfaction with salary level may be a prerequisite for artisan retention. Herzberg, Mausner and Snyderman (1959) classified salary as a hygiene factor (which might prevent motivation). Development opportunities are classified as a motivator (which might lead to motivation). Therefore, salary requirements might need to be satisfied before artisans can be motivated by other factors (e.g. development opportunities). If employees receive salaries that are lower than what others in similar jobs get, they become dissatisfied and their intention to leave increases (Afolabi, 2002).

From the perspective of self-determination theory (Gagné \& Deci, 2005), identification with an organisation and internalisation of its values are affected by work climates that promote satisfaction of the needs for autonomy, competence and relatedness. In this regard, remuneration and development opportunities should be structured in such a way that they enhance artisans' intrinsic motivation and promote their internalisation of extrinsic motivation by focusing on their needs for autonomy, competence and relatedness.

Table 3 provides a summary of the results regarding factors that are important for artisan retention and whether they appear on the lists of retention factors as reported by Kaye and JordanEvans (2002) and Jordaan and Barry (2009).

Of the 13 factors that were identified in this study, six factors were confirmed in a previous study (see Kaye \& Jordan-Evans, 2002). These included remuneration, the working environment, working relationships and management. At a national level, seven factors were confirmed by the research of Jordaan and Barry (2009), namely remuneration, the working environment, job security, equality, management, recognition and development opportunity. The factors that were not confirmed by either one of the studies mentioned above may be inherent to the specific organisation where the research was conducted. These factors included change management, belongingness, the merit system and employee wellness. The importance of remuneration as a retention factor was confirmed by all three studies. From the additional factors that were identified by the participants, it is clear that organisations should not rely purely on remuneration as a retention strategy.

According to the conservation of resources theory of Hobfoll (1998), individuals seek and acquire resources that they value or that serve as a means for attaining their objectives. Salary and development opportunities are important resources because they help individuals cope with challenges and capitalise on opportunities. When these resources are threatened, artisans may experience diminished well-being, which may lead to their voluntarily leaving their jobs (Wright, 2010).

According to the participants' remarks, only two factors were perceived as being fully utilised by the organisation for retention: the working environment and job security. Both of these factors were perceived by the participants as being of low importance and were ranked fifth and seventh respectively. Factors that were of high importance to the participants, such as remuneration, development opportunity, recognition and management, were perceived as being only partially utilised for the retention of artisans. Although equality is also perceived to be a factor of high importance (ranked third), participants did not view this factor as being utilised at all for artisan retention. Working relationships received a ranking of sixth place, and, according to participants, this factor was also only partially utilised. Factors that were perceived to be of low importance, such as the merit system, job satisfaction, change management, belongingness and employee wellness, were also not being utilised at all by the organisation, according to the participants.

Keeping the above in mind, it can be concluded that artisan retention should be managed from an employee perspective. Therefore, communication between management and the employee is of the utmost importance when it comes to identifying the factors for retention and satisfying the needs of artisans. Kaye and Jordan-Evans (2002) support this, stating that when management asks employees about their needs, it allows the employee to feel cared for, valued and important, and this will often lead to stronger loyalty and commitment to the organisation.

\section{Limitations of the study}

The findings of this study are limited because it was mainly a qualitative study; therefore, the findings cannot be applied to other contexts. With regard to the sample, employees from only one department of the organisation and not the organisation as a whole were interviewed. Moreover, the entire sample consisted of male participants, which means that these findings cannot necessarily be applied to female employees. Another limitation is that the research was done from an artisan's perspective. There are other opinions, such as those of management and the Human Resources Department, that were not solicited in this research.

\section{Recommendations}

Based on the results of this study, the following recommendations can be made to retain artisans. First, organisations should provide equitable and fair (competitive) remuneration. Remuneration packages should also be benchmarked more often and remuneration reviews should be done from an employee perspective and not from a managerial perspective. Second, the organisation should encourage succession planning and identify roles for which employees may 
TABLE 3

Summary of artisan retention factors

\begin{tabular}{lll}
\hline Artisan retention factors and rank & $\begin{array}{l}\text { Appear in Kaye and } \\
\text { Jordan-Evans (2002) }\end{array}$ & $\begin{array}{l}\text { Appear in Jordaan } \\
\text { and Barry (2009) }\end{array}$ \\
\hline Remuneration (1) & Yes & Yes \\
Development opportunity (2) & Yes & Yes \\
Equality (3) & No & Yes \\
Recognition (4) & Yes & Yes \\
Management (5.5) & Yes & Yes \\
Working environment (5.5) & Yes & Yes \\
Working relationships (7) & Yes & No \\
Merit system (10.5) & No & No \\
Job satisfaction (10.5) & No & No \\
Change management (10.5) & No & No \\
Belongingness (10.5) & No & No \\
Employee wellness (10.5) & No & No \\
Job security (10.5) & No & Yes \\
\hline
\end{tabular}

be suited. It can also invest in cross-training, job shadowing, coaching, mentoring and cross-experience. It might also be beneficial for the organisation to run a mentoring and coaching programme for new employees in which only the top performers are allowed to become involved. Being a coach or mentor in this programme should be viewed as a status symbol, something to aspire to. Techniques to enhance employee attachment to the organisation (i.e. person-organisation fit selection approach and performance-based incentives) should be implemented.

In terms of future research, it is recommended that artisans from various organisations and in different industries be studied in order to obtain a more representative sample. Future research should focus on the views of female artisans regarding the perceived importance of these factors for artisan retention.

\section{REFERENCES}

Abraham, S. (2007). Employee retention requires personcentered plan. Construction News, 74(14), 12-13.

Afolabi, A.C. (2002). Influence of organisational climate and locus of control on job satisfaction and turnover intentions. Nigerian Journal of Psychology, 19(1), 102-113.

Bassi, L.J., \& Van Buren, M.E. (1999). Sharpening the leading edge. Training $\mathcal{E}$ Development, 53, 23-32.

Buhler, P.M. (2003). Managing in the new millennium: Understanding the manager's motivational tool bag. Supervision, 64(12), 20-22.

Centre for Development and Enterprise. (2007, October 6). The skills revolution: Are we making progress? In CDE in-depth report. Retrieved March 20, 2008, from http://www.cde.org. za/attachment_view.php?aa_id=196

Chew, Y.T. (2005). Achieving organisational prosperity through employee motivation and retention: A comparative study of strategic HRM practices in Malaysian institutions. Research and Practice in Human Resource Management, 13(2), 87-104.

Creswell, J.W. (1998). Qualitative inquiry and research design: Choosing among five traditions. Thousand Oaks, CA: Sage.

Creswell, J.W., \& Clark, V.P. (2007). Designing and conducting mixed methods research. Thousand Oaks, CA: Sage.

De Lange, J. (2007, November 22). Anglo Platinum skaal sy verwagte produksie vir die jaar verder af [Anglo Platinum further decreases its production for the year]. Beeld. Retrieved March 20, 2008, from http://152.111.1.251/argief/berigte/ beeld/2007/11/22/B1/3/jlplatarbeid.html

Dibble, S. (1999). Keeping your valuable employees. New York: Wiley.

Gagné, M., \& Deci, E.L. (2005). Self-determination theory and work motivation. Journal of Organizational Behavior, 26, 331362.
Grobler, P., Wärnich, S., Carrell, M.R., Elbert, N.F., \& Hatfield R.D. (2006). Human resource management in South Africa (3rd edn.). London: Thomson Learning.

Harris, J., \& Brannick, J. (1999). Finding and keeping great employees. New York: American Management Association.

Harvard Business School. (2006). The results-driven manager: Retaining your best people. Boston, MA: Harvard Business School Publishing.

Herzberg, F., Mausner, B., \& Snyderman, B. (1959). The motivation to work. New York: Wiley.

Hobfoll, S.E. (2001). The influence of culture, community and the nested-self in the stress process: Advancing conservation of resources theory. Applied Psychology: An International Review, 50, 337-369.

Jordaan, N., \& Barry, M.L. (2009). Investigating the reasons for lack of skilled artisans in South Africa: The perspective of artisans. South African Journal of Engineering, 20(1), 173-184.

Kaye, B., \& Jordan-Evans, S. (2002). Retention in tough times. Training and Development, 56(1), 32-37.

Kleynhans, J. (2007, August). Memorandum to the Chamber of Mines. Retrieved March 20, 2008, from http://www. solidaritysa.co.za/Home/wmview.php?ArtID=387

Levin, A., Mor Barak, M.E., \& Nissly, J.A.M. (2001). Antecedents to retention and turnover among child welfare, social work and other human services employees: What can we learn from past research? Social Service Review, 75, 626-661.

McCarter, J., \& Schreyer, R. (2000). Recruit and retain the best. Manassas Park, VA: Impact Publications.

Mengel, D. (2001). Top ten ways to retain high performance. People Dynamics, 19(9), 23-33.

Miles, M.B., \& Huberman, A.M. (1994). Qualitative data analysis: An expanded sourcebook (2nd edn.). Thousand Oaks, CA: Sage.

Moustakas C. (1994). Phenomenological research methods. London: Sage.

Newell, S. (2002). Creating the healthy organization. Well-being, diversity $\mathcal{E}$ ethics at work. London: Thomson Learning.

Parker, O., \& Wright, L. (2000). Pay and employee commitment: The missing link. Ivey Business Journal, 65, 70-79.

Ramlall, S. (2004). A review of employee motivation theories and their implications for employee retention within organizations. Journal of American Academy of Business, 5(1/2), 52-63.

Ryan, R.M., \& Deci, E.L. (2002). Overview of self-determination theory: An organismic-dialectical perspective. In E.L. Deci \& R.M. Ryan (Eds.), Handbook of self-determination research (pp. 3-33). Rochester, NY: The University of Rochester Press.

Sarantakos, S. (1998). Social research. Basingstoke: Macmillan.

Simpson, L. (2002). War for talent. Global HR, 54, 58-59.

South African Institute of Race Relations. (2007, December 12). The skills shortage: Urban legend or fatal constraint? In Fast Facts. Retrieved March 20, 2008, from http://www.sairr. org.za/research-and-publications/fast-stats-online/fastfacts-2007/fast-facts-no-12-december-2007.html

Toracco, R.J. (2000). A theory of knowledge management. Advances in Developing Human Resources, 2(1), 38-62.

Totta, J.M., \& Burke, R.J. (1995). Integrating diversity and equality into the fabric of the organization. Women in Management, 10(7), 32-39.

Willis-Shattuck, M., Bidwell, P., Thomas, S., Wyness, L., Blaauw, D., \& Ditlopo, P. (2008). Motivation and retention of health workers in developing countries: A systematic review. BMC Health Services Research, 8, 47.

Wright, T.A. (2010). The role of psychological well-being in job performance, employee retention and cardiovascular health. Organizational Dynamics, 38(1), 13-23. 